\title{
Lecturers Expectancies on Students at Higher Education
}

\author{
Yufiarti $^{1}$, Diyah Yuli Sugiarti ${ }^{2}$ \\ Universitas Negeri Jakarta, Jakarta, Indonesia ${ }^{1}$ \\ Postgraduate Universitas Islam “45” Bekasi.Indonesia ${ }^{2}$ \\ \{yufiarti@yahoo.co.id ${ }^{1}$, diyah.ys@gmail.com $\left.{ }^{2}\right\}$
}

\begin{abstract}
Brain-based teaching started from the changing of the lecturer mindset with a positive view of students. The Lecturers have a significant effect on the student's academic achievement. The objective of this research was to describe the characteristics of the lecturers that support the implementation of brain-based teaching. This research used a survey on 42 lecturers in a private university. The data analysis used descriptively. The data collection used the teacher's expectation scale (TES). The research concluded that the lecturers have positive expectancies on student's academic. That characteristic support the implementation of brain-based teaching.
\end{abstract}

Keywords: Brain-Based Teaching, Higher Education, Lecturer Expectancies

\section{Introduction}

Many research conduct the study of brain-based teaching, such as Reynaldo and Laliene, implemented the study determined the essential elements of outcomes-based teaching and learning (OBTL) component of outcomes-based education (OBE) cycle. Though, an INSET in the public school enhanced opportunities to exhibit teaching attributes such as vivacity, sense of humor, creativity, inquisitiveness, concentration, cautiousness, and dynamism in the achievement of the 21 st-century skill, however, these attributes remained uniquely apparent in every individual teacher. Reflection Dreaming to acquire many of these attributes amongindividual teacher propelled their authentic experience and sincerity to integrate appropriate OBTL activities, which emphasized its four spiral elements, by which the learners would: ownknowledge in discovering experiences (sarili), master skill in critical evaluation (husay), engage understating and reflection in dialogical abstraction (saysay), and achieve wonderment in active experimentation (ambag) [1]-[6].

Other research Christine M. Rubie-Davies, Robert Rosenthal, examine the effectiveness of a teacher expectation intervention across different schools, grade levels, socioeconomic levels, ethnicities, and gender in terms of student mathematics achievement. Teachers were randomly assigned to intervention and control groups, and through professional development, workshops were trained in the practices of teachers who have high expectations for all students. To examine the effectiveness of a teacher expectation intervention across different schools, grade levels, socioeconomic levels, ethnicities, and gender in terms of student mathematics achievement[1], [7]-[9].

Brain-based teaching is a learning strategy that is based on the working of the brain. Steps in this implementation are started from the changing of the lecturer mindset with a positive view of students, then leads to a model of effective lecturer characteristic. Carrying a fun 
lecture by creating a conducive environment, multiple development intelligence, optimizing memory and improving emotional intelligence [1], [3], [6], [8], [10].

The implementation of Brain-based Teaching demands the readiness of educational institution, especially the preparation of facilities and infrastructures that relates to the digital era. Facilities that need to be preparedincludea computer, internet connection, and library. Besides, the preparation of human resources includesthe personality of the lecturers. Although each lecturer has and shows on many levels, the attributes that support brain-based teaching can be grouped into three outlines; they are motivating personality, orientation to success, and a professional attitude. Motivating personality includes having enthusiasm, variation, warmth,and humor. These attributes help to get and retain students to get involved and interested in learning. Orientation to success means lecturers believe in themselves and their ability to be successful. Attributes such as expecting success and being the booster and supporter of the students expressed this orientation. Through the application of Barain-based teaching, the learning would be effective, creative, interactive and fun. Numerous studies exploring the effects of teachers' explicit expectations on actual student achievement have been conducted. Although few question the existence of differential teacher expectations, there is a debate about the size of teacher expectation effects on students' achievement. A recent meta-analysis of 674 experimental and naturalistic studies found that the average expectation effect size across all students was a modest $\mathrm{d} 1 / 4$, however, based on 11 naturalistic studies, Jussim. Robustelli and Cain argue that teacher expectations predicted student achievement because their expectations were accurate[8], [10]-[13].

The lecturer who is successful in the era of intelligence has the ability in ten aspects [2], [3], [6], [7], [9], [10], [13]-[15]:

- Understanding what happens in the brain when students learn

- Having the characteristics of Care, Creativity, Courage

- Facilitating different learning styles

- Developing multiple intelligence of students

- Applying the variation in learning

- Creating an intellectually challenging environment

- Establishing a healthy lifestyle (healthy brain)

- Using a variety of music

- Applying a variety of assessment

- Reflecting on learning

Brain working-based learning starting from lecturers understanding of how the brain works so that lectures have adequate knowledge of how learning occurs. Although each lecturer has and shows on many levels, the attributes that support brain-based teaching can be grouped into three outlines; they are motivating personality, orientation to success, and a professional attitude [3], [6], [16].

They are having a personality that can motivate like enthusiasm, variation, warmth,and humor. These attributes help to get and retain students to get involved and interested in learning. Orientation to success means lecturers believe in themselves and their ability to be successful. Professional attitude means that lectures are more focused on helping students learn. Effective professional lecturers are lecturers that are knowledgeable and deft so that students see them as a trustworthy lecturer [7], [16].

Lecturers who succeed in motivating and upliftingseems to enjoy what they do; they supported the students. One of the lecturer characters that closely related to the expected result is the enthusiasm of students. Lecturers who are eager to convey to the students confidently 
and enjoy what they do, they care about the students and the subjects they teach is valuable and enjoyable. Teaching enthusiastically helping students to keep doing the task, motivate them, and to lead students to improve learning and satisfying. Lecturers who enthusiastically convey the subject have a different way of speech, gesture, and facial expression are diverse. Lecturers who enthusiastically walked around the classroom, starting from the front to the back of the classroom. They discuss with the exciting use of hand gestures, head, and shoulders to reinforce or affirm the intent / their words. They make eye contact with the students, to encourage the students to participate, gather and use feedback from all students [7], [14]-[16].

Lecturers who are friendly and fun is an important factor in the promotion, support, relaxing, satisfying, through education to the students. By supporting the productive and safe environment, friendly and fun indirectly increase the learning motivation. Lecturer stated friendliness is a positive thing, supporting interpersonal relationship with students. This positive relationship in the classroom helps the students progress - orientation to success. Lecturers are expected to have a positive outlook. They believe that their students can learn and they can help their students to achieve the learning objectives [7], [14]-[16].

Students can catch the expectations that you show through communication such as gestures you provided. If you have low expectations for certain students, not only the student, but other students may be able to feel it if they have the perception that it is intended for them. As a result, students tend to take on and internalize every lecturer's behavior who have low expectations, the effect for students can lower their expectations [8], [10]-[12], [17].

Lecturers that effectively encourage and support students, handling the needs of students, to achieve successful learning. They admit the effort and students' potential. The general character of the effective lecturers is to have a task orientation and being deft in the classroom. The main activities in the classroom are learning. The deft lecturer is firm and focus on activities in the classroom and help students learn [7], [14]-[16].

On the other hand,brain working-based learning requires the mindset of lecturers. The lecturers hope to students is important to interact with students. Lecturer plays an important role in identifying the learning styles of students so that in designing learning styles and apply learning style can be optimized. In this case, the lecturer uses variations in implementing the learning so that children develop multiple intelligences. According to Howard Gardner, man has eight multiple intelligences, namely: linguistic intelligence, visual-spatial, bodykinesthetic, musical, logical-mathematical, interpersonal, intrapersonal, and naturalistic [8], [10]-[12], [17].

\section{Method}

The research method used survey on 42 lecturers at a private university. The data analysis used percentage. The data collection used the instrument in the form of self-report. Instrument contained 24 statements answered based on self-reports of lecturers.

\section{Result and discussion}

Based on data collection of 42 lecturers who joined brain-based teaching training can be described as follows: Characteristics of lecturers in accordance with the implementation of brain-based teaching includes 24 following characteristics: 
Table 1. Characteristics of Lecturers

\begin{tabular}{clcc}
\hline No & \multicolumn{1}{c}{ Pernyataan } & F & $\mathbf{\%}$ \\
\hline 1 & Believing that all students are intelligence & 42 & 100 \\
2 & Positive expectation to students & 42 & 100 \\
3 & Students are unique and have different ability & 42 & 100 \\
4 & Students have different learning style & 42 & 100 \\
5 & Conveying the learning objective clearly & 42 & 100 \\
6 & Arranging logic standard & 42 & 100 \\
7 & Dynamic & 42 & 100 \\
8 & Enthusiast & 40 & 95 \\
9 & Expressive & 40 & 95 \\
10 & Confident & 40 & 95 \\
11 & Respect their students & 42 & 100 \\
12 & Helping theor students not to be easily give up in & 38 & 90 \\
& learning & & \\
13 & Directing students to an increase learning & 42 & 100 \\
14 & Giving comprehensive explanation & 42 & 100 \\
15 & Setting their explanation speed & 42 & 100 \\
16 & Connecting the learning material with the students' & 42 & 100 \\
& interest & & \\
17 & Creating fun atmosphere & 42 & 100 \\
18 & Vary in learning method & 42 & 100 \\
19 & Developing method of memorization easily & 42 & 100 \\
20 & Giving remedial chance & 42 & 100 \\
21 & Discipline in finishing activities & 42 & 100 \\
22 & Rarely in criticize & 42 & 100 \\
23 & Giving input to students & 42 & 100 \\
24 & Giving time to respong question & 42 & 100
\end{tabular}

Based on Table 5 above, it can be concluded that in general, the lecturers have overall lecturer characteristicsby the learning brain-based teaching (range of scores 90-100\%) on each characteristic. Thus in terms of the characteristics of the lecturer, it can be concluded that the lecturers have had the characteristics that correspond to the application of brain-based teaching in the digital age [1], [2], [6], [16]. 


\section{Conclusion}

Brain-based teaching is a learning strategy that is based on the working of the brain. Steps in this application start from a change of lecturer mindset with a positive view of the students, then leads to a model of effective lecturer characteristics. This study concluded that lecturershad had the characteristics that correspond to the application of brain-based teaching in the digital age.

\section{References}

[1] D. J. Connell, Brain-Based Strategies to Reach Every Lerner. USA: Schoolastic Inc, 2005.

[2] Given and K. Barbara, Teaching to The Brain's Natural Learning Systems. USA: Association for Supervision and Curriculum Development, 2002.

[3] E. Jensen, Pemelajaran Berbasis-Otak. Paradigma Pengajaran Baru. Jakarta: PT. Indeks, 2011.

[4] Many, "The study of brain based teaching." 2016.

[5] Reynaldo and Laliene, "The study of brain based teaching." 2016.

[6] D. A. Sousa, How The Brain Learns, 3rd editio. California: Corwin Press, 2006.

[7] Christine M. Rubie-Davies and R. Robert, "Examine the effectiveness of a teacher expectation intervention across different schools." 2016.

[8] T. Buzan and B. Barry, Use Your memory. London: Guild Publishing, 1986.

[9] H. Gardner, "Multiple intelligences," Minnesota Cent. Arts Educ., vol. 5, no. 56, 1992.

[10] T. Buzan and B. Barry, "The power of verball intelligence," in 10 ways to tap into your verbal genius, USA: Harper Collins Publishers, 2002.

[11] T. Buzan and B. Barry, "The Mind Map Book," in How to use Radiant Thinking to Maximize your Brain's Untapped Potential, USA: Dutton, 1990.

[12] T. Buzan and B. Barry, Use Your Head. London: Guild Publishing, 1984.

[13] T. Buzan and B. Barry, The power of spiritual intelligence. London: Thorsons, 2001.

[14] P. Suparno, Teori Inteligensi Ganda dan Aplikasinya di Sekolah. Yogyakarta: Kanisius, 2003.

[15] A. Thomas, "Multiple Intelligence in the Classroom." 1997.

[16] Given and Barbara.K, Brain-Based Teaching: Merancang Kegiatan Belajar-Mengajar yang Melibatkan Otak Emosional,Sosial, Kognitif, Kinestetis, dan Reflektif. Bandung: Penerbit Kaifa, 2007.

[17] C. P. W. Barbara, Word and the mind. New York: Oxford University Press, 2010. 